\title{
Grape Composition under Abiotic Constrains: Water Stress and Salinity
}

\author{
José M. Mirás-Avalos * and Diego S. Intrigliolo \\ Departamento de Riego, Centro de Edafología y Biología Aplicada del Segura, Consejo Superior de Investigaciones \\ Científicas, Murcia, Spain
}

Water stress and increasing soil salt concentration represent the most common abiotic constrains that exert a negative impact on Mediterranean vineyards performance. However, several studies have proven that deficit irrigation strategies are able to improve grape composition. In contrast, irrigation with saline waters negatively affected yield and grape composition, although the magnitude of these effects depended on the cultivar, rootstock, phenological stage when water was applied, as well as on the salt concentration in the irrigation water. In this context, agronomic practices that minimize these effects on berry composition and, consequently, on wine quality must be achieved. In this paper, we briefly reviewed the main findings obtained regarding the effects of deficit irrigation strategies, as well as irrigation with saline water, on the berry composition of both red and white cultivars, as well as on the final wine. A meta-analysis

OPEN ACCESS

Edited by:

Nadia Bertin,

Plantes et Système de cultures Horticoles (INRA), France

Reviewed by:

Claudio Lovisolo,

University of Turin, Italy

Jose Carlos Herrera

University of Natural Resources and Life Sciences, Vienna, Austria

*Correspondence: José M. Mirás-Avalos jmmiras@cebas.csic.es

Specialty section:

This article was submitted to

Crop Science and Horticulture, a section of the journal Frontiers in Plant Science

Received: 17 February 2017 Accepted: 08 May 2017 Published: 30 May 2017

Citation: Mirás-Avalos JM and Intrigliolo DS (2017) Grape Composition under

Abiotic Constrains: Water Stress and Salinity. Front. Plant Sci. 8:851. doi: 10.3389/fpls.2017.00851 was performed using published data for red and white varieties; a general liner model accounting for the effects of cultivar, rootstock, and midday stem water potential was able to explain up to $90 \%$ of the variability in the dataset, depending on the selected variable. In both red and white cultivars, berry weight, must titratable acidity and $\mathrm{pH}$ were fairly well simulated, whereas the goodness-of-fit for wine attributes was better for white cultivars.

Keywords: anthocyanins, deficit irrigation, saline water, sugars, titratable acidity, Vitis vinifera L., wine

\section{INTRODUCTION}

Grape quality is a complex concept that mainly refers to berry chemical composition, including sugars, acids, phenolics, and other aroma compounds (Lund and Bohlmann, 2006). The composition and concentration of these chemical compounds change during berry development and can be affected by many factors, either environmental, endogenous, or management practices (Jackson and Lombard, 1993; Dai et al., 2011). In this context, climate change will pose relevant constraints to grape and wine production in the coming years (Santos et al., 2012). Increasing temperatures, lower rainfall amounts, and heat waves are expected to become more frequent over the course of this century (IPCC, 2014). However, the most imminent challenges that grape, wine, and raisin industries must face, especially in arid and semi-arid regions, are increasing drought and salinity due to higher evaporation and declining water availability (Schultz and Stoll, 2010).

The effects of water stress on grapevine (Vitis vinifera L.) metabolism, vegetative development, productive performance, and berry composition have been widely studied for many combinations of rootstocks, cultivars, and climate conditions (e.g., Acevedo-Opazo et al., 2010; Intrigliolo et al., 2016). However, the extents to which berry secondary metabolites and wine composition are affected by water stress have seldom been assessed. 
Salinity effects on vine performance and berry composition have been studied mainly in Australia (e.g., Stevens et al., 2011; Walker et al., 2014) but research in other areas is scarce. Reported results suggest that cultivar, rootstock, salt concentration, and time of exposure to saline conditions are relevant factors for the final berry and wine composition.

This review summarizes the main findings on the effects of water and salinity stresses on berry and wine composition, both in red and white cultivars.

\section{WATER STRESS}

Water is critical for viticulture sustainability because grape production, quality, and economic viability largely depend on water availability (Medrano et al., 2015). A great effort has been devoted to assess the influence of grapevine water status on berry composition, mainly on red varieties under semi-arid conditions, accounting for total soluble solids (TSS), titratable acidity, and $\mathrm{pH}$, although some other traits such as malic and tartaric acid concentrations, phenolics, anthocyanins, and tannins have been considered in some studies (e.g., Peyrot des Gachons et al., 2005; Bindon et al., 2008; van Leeuwen et al., 2009). However, detailed assessments of aroma precursors (Savoi et al., 2016), individual anthocyanins (Bindon et al., 2008, 2011; Santesteban et al., 2011; Cook et al., 2015; Hochberg et al., 2015), or phenolics (Ojeda et al., 2002; Ollé et al., 2011) have rarely been undertaken.

Reported results suggest that many factors including genotypes, climate, soil, and vineyard management can influence vine response to water stress, as reviewed by Medrano et al. (2015) and confirmed by the meta-analysis reported by LavoieLamoureux et al. (2017). In water-limited areas, deficit irrigation practices can be a useful tool for manipulating berry composition to enhance and modulate the season-to-season variability in red wine composition (Intrigliolo et al., 2012), leading to changes in wine sensory properties (Chapman et al., 2005). However, the intensity of water stress and its period of occurrence over the grapevine growing cycle are of paramount importance. Apart from the variability in the response due to genotypes, environment, experimental setup, management practices among others, water stress imposed at pre-veraison stages induces major metabolic modifications in the berry that can be maintained even after re-watering (Shellie, 2014; Keller et al., 2016). In contrast, post-veraison water deficit effects are more variable, preventing a generalization of its positive or negative influences (Girona et al., 2009; Intrigliolo and Castel, 2010; Munitz et al., 2017).

In general, a moderate water stress reduces berry weight and titratable acidity but increases TSS, total anthocyanins, and phenolics concentrations in red grapes (Romero et al., 2010), improving berry quality. However, when a certain threshold of water stress is surpassed, these beneficial effects are no longer observed. This response seems to depend on the combination rootstock/cultivar as well as on soil and climate conditions. Water potential is the main indicator of vine water status and some authors established relations between this indicator and berry compositional traits (Salón et al., 2005; van Leeuwen et al., 2009; Romero et al., 2010; Shellie and Bowen, 2014); however, these relationships differ amongst cultivars, region, year, soil types, and management practices. Usually, higher levels of water stress are reported to reduce berry weight and malic acid concentrations while increasing anthocyanins and sugar contents up to a threshold were they are negatively affected. However, these responses depend on other factors such as crop load, vineyard age, fertilization, soil type, berry maturation stage at harvest, and canopy development, amongst others. Furthermore, few studies have accounted for the effects that water stress might exert on berry skin and seeds (Ojeda et al., 2002; Roby and Matthews, 2004; Bucchetti et al., 2011; Merli et al., 2015), even though this issue is relevant to discern between the effects of dilution of components or to what extent water stress is affecting compound synthesis and metabolism. Ojeda et al. (2002) imposed three levels of water deficit to Shiraz grapevines and observed that the concentration of phenolic compounds increased in berry skins due to berry size reduction; however, timing of stress occurrence and its severity could lead to negative effects on phenolic compound concentrations. Ollé et al. (2011) observed that water deficits affected differently the anthocyanin composition of Shiraz berries and suggested a differential regulation of the genes involved in the last steps of the anthocyanin biosynthesis pathway. In this sense, Hochberg et al. (2015) found that water stress modified polyphenol metabolism of Shiraz and Cabernet Sauvignon depending on the phenological stage, inducing the accumulation of stress-related metabolites such as proline and ascorbate. Cook et al. (2015) reported that sustained deficit irrigation increased the concentrations of di-hydroxylated anthocyanins while regulated deficit irrigation increased those of tri-hydroxylated anthocyanins. It has been shown that grapevine responds to drought by modulating several secondary metabolic pathways, altering the abundance of some transcripts and metabolites involved in phenyl propanoid, isoprenoid, carotenoid, amino acid, and fatty acid metabolism, as observed for Cabernet Sauvignon and Chardonnay (Deluc et al., 2009) and Sauvignon vert (Savoi et al., 2016). This might affect flavor and quality characteristics of grapes and wines.

In this context, we attempted a meta-analysis using published data from irrigation studies in field-grown red and white grapevine varieties from several wine regions worldwide (Supplementary Table 1). A search under the terms "grapevine," "water stress", and "berry composition" was carried out in the Web of Knowledge database. This yielded 184 references. Those works referred to potted vines and those not including leaf $\left(\Psi_{1}\right)$ or stem $\left(\Psi_{\text {stem }}\right)$ water potential measurements were discarded. When only one of these measurements was present, we used the relationships reported by Intrigliolo and Castel (2006) to obtain the values for the missing one. In the end, 48 works have been used (Supplementary Table 1).

Data retrieval from publications was carried out similarly to that described in Lavoie-Lamoureux et al. (2017). The following information was associated to the data in the database, when available: cultivar, country, year, treatment, rootstock, and developmental stage in which water stress was imposed (pre- or post-veraison).

Data were analyzed using the IBM SPSS Statistics for Windows, version 23.0 (IBM Corp., Armonk, NY, United States). 
Data on berry size and composition (and wine attributes, when available) were used as dependent variables, while $\Psi_{\text {stem }}$ was considered as a covariable and cultivar, rootstock, and timing when water stress was imposed as fixed factors. Moreover, Pearson's coefficient of correlation was used to assess the relationships among vine water status (as determined by predawn, leaf, and stem water potentials) and berry size and composition.

The final database contained 420 data points (298 for red and 122 for white varieties) obtained from 48 references published between 1979 and 2017 (Supplementary Table 1). Twenty different Vitis vinifera cultivars were represented (11 red and 9 white). The number of data retrieved per publication varied between 2 and 28, averaging 10.5. Merlot and Tempranillo were the most represented varieties (79 and 78 data, respectively) among the red ones. In the case of white cultivars, Sauvignon blanc showed the highest number of data with 48.

For red varieties, cultivar, timing, and $\Psi_{\text {stem intervened }}$ significantly on the model; whereas for white varieties the factors were cultivar, rootstock, and $\Psi_{\text {stem }}$ (Table 1). No significant interactions among factors were detected. Overall, the models explained between 2 and $99.4 \%$ of the variation in the data distribution, depending on the variable considered (Supplementary Table 2).

The different measurements for assessing vine water status (predawn, leaf, and stem water potentials) considered in the current study were significantly related to several grape and wine compositional attributes. In the case of red varieties, midday stem water potential measured before veraison $\left(\Psi_{\text {stempre }}\right)$ was significantly and positively correlated to berry weight and must titratable acidity, whereas it was negatively correlated to must TSS, malic acid concentration and wine $\mathrm{pH}$, tartaric acid, anthocyanins, and total phenolic index (TPI) (Table 2). The other measurements of water status were significantly correlated with a lower number of attributes; for instance, $\Psi_{\text {stem }}$ was positively correlated with berry weight and must titratable acidity and negatively correlated to TSS (Table 2). However, $\Psi_{\text {stem }}$ is the most widely used measurement for assessing vine water status and thus we used it for depicting the relationships between berry traits and water stress.

In the case of red varieties, berry weight tended to decline with increasing $\Psi_{\text {stem }}$; however, the slope of this decrease depended on the cultivar (Supplementary Figure 1). This suggests that genetics may play a relevant role on the response of grapevines to water stress and those cultivars with small berries, such as Cabernet Sauvignon, suffer less important reductions when they are grown within a given interval of $\Psi_{\text {stem. }}$. In contrast, cultivars with large berries, such as Bobal or Merlot, seem to be more sensitive to little variations in grapevine water status.

The dataset did not show a clear relation between $\Psi_{\text {stem }}$ and TSS in the berries (Supplementary Figure 1). Nevertheless, a certain degree of water stress (up to $-1.3 \mathrm{MPa}$ ) was beneficial for sugar accumulation in the berry. When this threshold was surpassed, the concentration of TSS decreased. Similarly, no clear trend was observed for titratable acidity and anthocyanins (Supplementary Figure 1). However, Merlot berries showed a
TABLE 1 | Factors included in the first univariate general linear model performed on the red and white varieties databases.

\begin{tabular}{|c|c|}
\hline Factors & $p$-value \\
\hline \multicolumn{2}{|l|}{ Red varieties } \\
\hline Cultivar & $<0.001$ \\
\hline Rootstock & ns \\
\hline Timing & $<0.05$ \\
\hline$\Psi_{\text {stem }}$ & $<0.05$ \\
\hline Cultivar $\times$ rootstock & ns \\
\hline Cultivar $\times$ timing & ns \\
\hline Cultivar $\times \Psi_{\text {stem }}$ & ns \\
\hline Roostock $\times$ timing & ns \\
\hline Rootstock $\times \Psi_{\text {stem }}$ & ns \\
\hline Timing $\times \Psi_{\text {stem }}$ & ns \\
\hline Cultivar $\times$ rootstock $\times$ timing & ns \\
\hline Cultivar $\times$ rootstock $\times \Psi_{\text {stem }}$ & ns \\
\hline Cultivar $\times$ timing $\times \Psi_{\text {stem }}$ & ns \\
\hline Rootstock $\times$ timing $\times \Psi_{\text {stem }}$ & ns \\
\hline Cultivar $\times$ rootstock $\times$ timing $\times \Psi_{\text {stem }}$ & ns \\
\hline \multicolumn{2}{|l|}{ White varieties } \\
\hline Cultivar & $<0.001$ \\
\hline Rootstock & $<0.01$ \\
\hline Timing & ns \\
\hline$\Psi_{\text {stem }}$ & $<0.01$ \\
\hline Cultivar $\times$ rootstock & ns \\
\hline Cultivar $\times$ timing & ns \\
\hline Cultivar $\times \Psi_{\text {stem }}$ & ns \\
\hline Roostock $\times$ timing & ns \\
\hline Rootstock $\times \Psi_{\text {stem }}$ & ns \\
\hline Timing $\times \Psi_{\text {stem }}$ & ns \\
\hline Cultivar $\times$ rootstock $\times$ timing & ns \\
\hline Cultivar $\times$ rootstock $\times \Psi_{\text {stem }}$ & ns \\
\hline Cultivar $\times$ timing $\times \Psi_{\text {stem }}$ & ns \\
\hline Rootstock $\times$ timing $\times \Psi_{\text {stem }}$ & ns \\
\hline Cultivar $\times$ rootstock $\times$ timing $\times \Psi_{\text {stem }}$ & ns \\
\hline
\end{tabular}

Non-significant factors were not included in the final model. ns, non-significant.

steep increase in the concentration of anthocyanins when $\Psi_{\text {stem }}$ varied from -0.5 to $-1.5 \mathrm{MPa}$.

Winemaking was not usually involved in the experimental design and a low amount of data was available for performing this meta-analysis. The lack of significant relations may have been caused by the variability in winemaking procedures in the different studies (yeast strain, fermentation temperature, and time, etc.). However, lower pre-veraison midday stem water potentials were significantly correlated with higher values of anthocyanins and TPI in wines (Table 2).

In the case of white varieties, data availability is much lower and, usually, studies are referred to cool climates. In this case, a significant but slight trend to lower berry weights with increasing water stress was observed (Supplementary Table 3). Cultivar seems to have a strong effect since Albariño berries remained almost unaffected whereas Sauvignon Blanc or Riesling berries were strongly reduced in terms of weight when $\Psi_{\text {stem }}$ became more negative (Supplementary Figure 2). It must be noticed, 
TABLE 2 | Pearson's correlation coefficients $(r)$ among different modalities of vine water status assessment and berry size and compositional traits for red cultivars.

\begin{tabular}{|c|c|c|c|c|c|}
\hline & & $\Psi_{\mathrm{pd}}$ & $\Psi_{\text {stempre }}$ & $\Psi_{\text {stempost }}$ & $\Psi_{\text {stem }}$ \\
\hline & Significance & 0.000 & 0.000 & 0.000 & 0.000 \\
\hline \multirow[t]{3}{*}{ Total soluble solids } & $r$ & -0.199 & -0.419 & -0.453 & -0.234 \\
\hline & Significance & 0.001 & 0.000 & 0.000 & 0.000 \\
\hline & $n$ & 286 & 126 & 138 & 286 \\
\hline & Significance & 0.024 & 0.055 & 0.989 & 0.208 \\
\hline & $n$ & 196 & 78 & 90 & 196 \\
\hline \multirow[t]{3}{*}{ Titratable acidity } & $r$ & 0.171 & 0.200 & 0.166 & 0.162 \\
\hline & Significance & 0.005 & 0.040 & 0.072 & 0.008 \\
\hline & $n$ & 266 & 106 & 118 & 266 \\
\hline Malic acid & $r$ & 0.065 & 0.384 & 0.137 & 0.086 \\
\hline & Significance & 0.641 & 0.507 & 0.332 & 0.458 \\
\hline & $n$ & 84 & 29 & 29 & 84 \\
\hline \multirow[t]{3}{*}{ Anthocyanins } & $r$ & -0.029 & -0.027 & 0.413 & -0.021 \\
\hline & Significance & 0.796 & 0.914 & 0.079 & 0.852 \\
\hline & $n$ & 81 & 19 & 19 & 81 \\
\hline \multirow[t]{3}{*}{ Total phenolics index } & $r$ & 0.145 & -0.276 & 0.254 & 0.140 \\
\hline & Significance & 0.269 & 0.173 & 0.211 & 0.285 \\
\hline & $n$ & 60 & 26 & 26 & 60 \\
\hline \multirow[t]{3}{*}{ Wine alcohol } & $r$ & -0.213 & -0.140 & -0.273 & -0.189 \\
\hline & Significance & 0.055 & 0.402 & 0.097 & 0.088 \\
\hline & $n$ & 82 & 38 & 38 & 82 \\
\hline & Significance & 0.973 & 0.430 & 0.485 & 0.707 \\
\hline & $n$ & 70 & 32 & 32 & 70 \\
\hline \multirow[t]{3}{*}{ Wine tartaric acid } & $r$ & 0.050 & -0.619 & -0.156 & -0.126 \\
\hline & Significance & 0.720 & 0.001 & 0.445 & 0.364 \\
\hline & $n$ & 54 & 26 & 26 & 54 \\
\hline \multirow[t]{3}{*}{ Wine anthocyanins } & $r$ & 0.049 & -0.434 & -0.047 & 0.046 \\
\hline & Significance & 0.676 & 0.013 & 0.800 & 0.693 \\
\hline & $n$ & 76 & 32 & 32 & 76 \\
\hline \multirow[t]{3}{*}{ Wine total phenolics index } & $r$ & -0.061 & -0.623 & -0.265 & -0.068 \\
\hline & Significance & 0.604 & 0.000 & 0.143 & 0.562 \\
\hline & $n$ & 76 & 32 & 32 & 76 \\
\hline
\end{tabular}

Significant correlations are shown in bold. $\Psi_{\text {pd, }}$, pre-dawn leaf water potential; $\Psi_{\text {stempre, }}$ pre-veraison midday stem water potential; $\Psi_{\text {stempost, }}$ post-veraison midday stem water potential; $\Psi_{\text {stem, }}$ midday stem water potential. Significance indicates the $p$-value for each correlation. $n$, number of data points.

however, that the levels of water stress experienced by the different cultivars were not the same.

In white cultivars, TSS seemed to be unaffected by water stress when the whole dataset was accounted for (Supplementary Figure 2). However, Riesling, Godello, Albariño, or Treixadura tended to show high TSS values with increasing water stress. In contrast, Muscat and Sauvignon Blanc showed similar TSS for

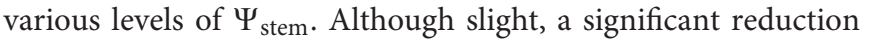
in titratable acidity with increasing water stress was detected (Supplementary Figure 2). This relation was more marked in Godello and Riesling. Since these data come from experiments performed in cool climates, severe water restriction has rarely 
been achieved and $\Psi_{\text {stem }}$ varied within narrow ranges. Only for Sauvignon Blanc and Muscat, $\Psi_{\text {stem }}$ reached values close to $-1.5 \mathrm{MPa}$ or even more negative. Similarly to red cultivars, winemaking has rarely been carried out. Nevertheless, a trend to higher alcohol contents with increasing $\Psi_{\text {stem }}$ was observed (data not shown). In addition, more negative $\Psi_{\text {stem }}$ values led to lower titratable acidities (Supplementary Figure 2).

Water stress or deficit irrigation strategies effects on wine volatiles have seldom been assessed; likely because winemaking practices can modulate wine composition to a great extent (Ilc et al., 2016). Recently, Talaverano et al. (2017) reported that higher alcohols such as 2-methyl-1-butanol and 2,3-butanediol, as well as C6 compounds such as 1-hexanol increased in Tempranillo wines under water stress conditions in Western Spain; in contrast, 2-phenylethyl acetate concentration was significantly decreased by water deficit. Despite the fact that other 16 compounds did not present significant differences caused by vine water status, changes in 2-phenylethyl acetate might have consequences on wine sensory perception because this compound provides floral and sweet notes, whereas 2-methyl1-butanol, 2,3-butanediol, and 1-hexanol provide malt, burned and creamy notes to wines. In this line of work, MendezCostabel et al. (2014) reported that moderate water stress would reduce 3-isobutyl-2-methoxypyrazine concentration, and thus the intensity of green aromas, without altering that of C6 compounds in Merlot grapes and wines. Finally, Ou et al. (2010) observed that deficit irrigation affected the concentrations of terpene alcohols and norisoprenoids in wines, whereas it had not consistent influence on ester concentrations.

\section{SALINE STRESS}

Continued rates of water extraction for agriculture, declining rainfall trends and increased portioning of water for ecosystem servicing have led to unsustainable levels of water consumption in many parts of the world (Hamilton et al., 2007). This has focused the attention on the use of alternative water sources such as municipal and winery wastewaters for irrigation instead of scarce water sources (Laurenson et al., 2012). However, wastewater may contain constituents of potential concern such as heavy metals, pathogens, and a high biological oxygen demand (Mosse et al., 2011). Furthermore, the salt content of these recycled waters, and the concentrations of specific salt ions $\left(\mathrm{Na}^{+}, \mathrm{K}^{+}\right)$, is of paramount importance in relation to soil structure, vine performance, and berry and wine composition (Laurenson et al., 2012; Mosse et al., 2013; Netzer et al., 2014). In certain areas, such as the Mediterranean, water reuse can be considered as a cost-effective solution for agriculture since it reduces the need to develop new water resources and provides an adaptive solution to climate change along with an increase in the social and environmental value of water (Costa et al., 2016). Although wastewater use might mitigate drought stress, the short and midterm detrimental effects of salt stress must be quantified, as pointed out by several authors (Laurenson et al., 2012; Costa et al., 2016).
Rising salinization of soil could pose a serious threat to grape growing because most irrigated vineyards, especially those deficit-irrigated, are at risk due to dissolved salts in irrigation water (Keller, 2010). The deleterious effects of salinity on plant growth are caused by an osmotic effect in which the increase in soluble salt concentration of the soil solution imposes an osmotic drought on the plant and a toxic effect in which the tissue concentrations of the micronutrient chloride and the beneficial element sodium increase to toxic levels (Marschner, 1986).

Salinity damage has been a concern for a long time in Australian vineyards (e.g., Hickinbotham and Williams, 1933; Walker et al., 2014); however, studies in other areas are scarce. Usually, tolerance of grapevines to salinity is measured by yield performance and by the capacity for salt exclusion, necessary to prevent salt damage to leaves and to minimize $\mathrm{Cl}^{-}$and $\mathrm{Na}^{+}$ accumulation in grape juice and wine (Teakle and Tyerman, 2010). Nevertheless, the effects of salinity on berry or juice composition seem to depend on the combination of cultivar and rootstock and on the salt concentration in the irrigation water, as well as on its time of application over the growing season.

In a 6-year study on Colombard vines grafted onto Ramsey rootstock, Stevens et al. (2011) observed that saline irrigation applied at different stages over the growing cycle increased $\mathrm{Na}^{+}$concentration in juice over the first four seasons but in the last two seasons this concentration only increased in some of the treatments. In contrast, $\mathrm{Cl}^{-}$concentration in juice increased over the 6 years independently of the treatment. Interestingly, saline irrigation caused small variations in juice Brix, titratable acidity, $\mathrm{pH}$, and malate concentration. Recently, Degaris et al. (2016) proved that ion partitioning in grapevines and thus $\mathrm{Cl}^{-}, \mathrm{Na}^{+}$, and $\mathrm{K}^{+}$in berries and juice depends on the type of deficit irrigation applied in two red cultivars (Shiraz and Grenache). Partial root-zone drying reduced the concentration of these ions in the fruit of both cultivars when compared with a fully irrigated control and a deficit irrigated treatment.

The negative effects that salinity might provoke in grape composition can be reduced by the selection of a tolerant rootstock able to exclude salts. In a long-term trial, Walker et al. (2014) observed that Chardonnay and Shiraz vines showed a low yield and a high concentration of both chloride and sodium in grape juice ( $>500 \mathrm{mg} / \mathrm{L}$ ) when they were own-rooted. However, Chardonnay on C5 and Shiraz on C7 rootstocks had the lowest concentration of grape juice chloride and sodium $(<50 \mathrm{mg} / \mathrm{L})$. Moreover, TSS in juice was significantly reduced when Chardonnay vines were own-rooted in comparison with those grafted on rootstocks. These authors noted also significant differences in $\mathrm{pH}$ and titratable acidity as a function of rootstock in both cultivars. Finally, Walker et al. (2014) highlighted the different responses between cultivars; Shiraz vines had been less affected by prolonged exposure to salinity when compared with Chardonnay vines. An interesting feature of this study was that significant correlations between juice chloride and sodium concentrations and those found in trunk wood were detected. Previously, Walker et al. (2000) had observed that, under salinity conditions, rootstock would influence color density and anthocyanin concentration in the berries, detecting significant 
differences among rootstocks for wine titratable acidity and wine score.

From the sensory point of view, salinity derived attributes ("brackish," "seawater like," "soapy") are considered negative and had been correlated with high concentrations of $\mathrm{Na}, \mathrm{K}$, and $\mathrm{Cl}$ in wines (Mira de Orduña, 2010). In a study carried out on 4000 wines across 3 years, Kaufmann (1996) found a significant correlation between high chloride levels and arid producing regions. Average chloride levels of $0.69 \mathrm{mM}$ across all European red and white wines analyzed contrasted with the $3.78 \mathrm{mM}$ average for wines produced in the United States, Mexico, Argentina, and Australia.

\section{SUMMARY, CONCLUSIONS, AND IMPLICATIONS}

Under the current scenario of global change, the constraints that water scarcity and salinity might induce on grape composition are becoming increasingly important worldwide. These stresses may endanger viticulture sustainability in the medium term by reducing yields and grape composition. Despite the huge amount of work aiming at assessing the effects of water status on vine yield and grape composition, no clear relationships could be established between $\Psi_{\text {stem }}$ and berry size and composition. This is due to the large number of factors involved in grape composition development, indicating that water status might not be its main driver. The dataset analyzed in the current study proved that cultivar, timing of exposure to water restrictions and rootstock have a great influence on must and wine composition. Nevertheless, other factors, such as climate, leaf surface/yield ratio, training systems, amongst others, might interact with the

\section{REFERENCES}

Acevedo-Opazo, C., Ortega-Farias, S., and Fuentes, S. (2010). Effects of grapevine (Vitis vinifera L.) water status on water consumption, vegetative growth and grape quality: an irrigation scheduling application to achieve regulated deficit irrigation. Agric. Water Manage. 97, 956-964. doi: 10.1016/j.agwat.2010.01.025

Balint, G., and Reynolds, A. G. (2013). Effects of different irrigation strategies on vine physiology, yield, grape composition and sensory profile of Sauvignon blanc (Vitis vinifera L.) in a cool climate area. J. Int. Sci. Vigne Vin 47, 159-181. doi: 10.20870/oeno-one.2013.47.3.1547

Balint, G., and Reynolds, A. G. (2017). Irrigation level and time of imposition impact vine physiology, yield components, fruit composition and wine quality of Ontario Chardonnay. Sci. Hortic. 214, 252-272. doi: 10.1016/j.scienta.2016. 11.052

Bindon, K., Dry, P., and Loveys, B. (2008). Influence of partial rootzone drying on the composition and accumulation of anthocyanins in grape berries (Vitis vinifera c. Cabernet Sauvignon). Aust. J. Grape Wine Res. 14, 91-103. doi: 10.1111/j.1755-0238.2008.00009.x

Bindon, K., Myburgh, P., Oberholster, A., Roux, K., and Du Toit, C. (2011). Response of grape and wine phenolic composition in Vitis vinifera L. cv. Merlot to variation in grapevine water status. S. Afr. J. Enol. Vitic. 32, 71-88.

Bucchetti, B., Matthews, M. A., Falginella, L., Peterlunger, E., and Castellarin, S. D. (2011). Effect of water deficit on Merlot grape tannins and anthocyanins across four seasons. Sci. Hortic. 128, 297-305. doi: 10.1016/j.scienta.2011.02.003

Chapman, D. W., Roby, G., Ebeler, S. E., Guinard, J. X., and Matthews, M. A. (2005). Sensory attributes of Cabernet Sauvignon wines made from vines with ones that we focused on in the current study and should be taken into account for future research.

Water restrictions can be worsened by increasing salinity levels in soils and irrigation waters, especially in Mediterranean climates. Previous research proved that rootstocks possess different sensitivities to salinity levels in the soil and might reduce the concentration of saline ions in the fruit. Moreover, it seems that cultivars present also a different sensitivity to chloride and sodium.

\section{AUTHOR CONTRIBUTIONS}

Both JM-A and DI devised the structure and decided on the content of the paper, JM-A conducted the literature survey, and then JM-A wrote the manuscript. DI contributed to a general revision of the manuscript.

\section{FUNDING}

This research has been performed within the framework of the Spanish Ministry of Economy, Industry and Competitiveness MINECO (FEDER co-financing) Project AGL2014-54201C4-4-R.

\section{SUPPLEMENTARY MATERIAL}

The Supplementary Material for this article can be found online at: http://journal.frontiersin.org/article/10.3389/fpls.2017.00851/ full\#supplementary-material

different water status. Aust. J. Grape Wine Res. 11, 339.347. doi: 10.1111/j.17550238.2005.tb00033.x

Chaves, M. M., Santos, T. P., Souza, C. R., Ortuño, M. F., Rodrigues, M. L., Lopes, C. M., et al. (2007). Deficit irrigation in grapevine improves water-use efficiency while controlling vigour and production quality. Ann. Appl. Biol. 150, 237-252. doi: 10.1111/j.1744-7348.2006.00123.x

Choné, X. (2003). Terroir effect on the aromatic potential of Sauvignon Blanc. Progrès Agric. Vitic. 120, 63-68.

Cook, M. G., Zhang, Y., Nelson, C. J., Gambetta, G., Kennedy, J. A., and Kurtural, S. K. (2015). Anthocyanin composition of Merlot is ameliorated by light microclimate and irrigation in Central California. Am. J. Enol. Vitic. 66, 266-278. doi: 10.5344/ajev.2015.15006

Coombe, B. G., and Monk, P. R. (1979). Proline and abscisic acid content of the juice of ripe Riesling grape berries: effect of irrigation during harvest. Am. J. Enol. Vitic. 30, 64-67.

Costa, J. M., Vaz, M., Escalona, J., Egipto, R., Lopes, C., Medrano, H., et al. (2016). Modern viticulture in southern Europe: vulnerabilities and strategies for adaptation to water scarcity. Agric. Water Manage. 164, 5-18. doi: 10.1016/ j.agwat.2015.08.021

Dai, Z. W., Ollat, N., Gomès, E., Decroocq, S., Tandonnet, J. P., Bordenave, L., et al. (2011). Ecophysiological, genetic, and molecular causes of variation in grape berry weight and composition: a review. Am. J. Enol. Vitic. 62, 413-425. doi: 10.5344/ajev.2011.10116

De la Hera, M. L., Romero, P., Gómez-Plaza, E., and Martínez, A. (2007). Is partial root-zone drying an effective irrigation technique to improve water use efficiency and fruit quality in field-grown wine grapes under semiarid 
conditions? Agric. Water Manage. 87, 261-274. doi: 10.1016/j.agwat.2006. 08.001

Degaris, K. A., Walker, R. R., Loveys, B. R., and Tyerman, S. D. (2016). Comparative effects of deficit and partial root-zone drying irrigation techniques using moderately saline water on ion partitioning in Shiraz and Grenache grapevines. Aus. J. Grape Wine Res. 22, 296-306. doi: 10.1111/ajgwr.12220

Deluc, L. G., Quilici, D. R., Decendit, A., Grimplet, J., Wheatley, M. D., Schaluch, K. A., et al. (2009). Water deficit alters differentially metabolic pathways affecting important flavor and quality traits in grape berries of Cabernet Sauvignon and Chardonnay. BMC Genomics 10:212. doi: 10.1186/1471-216410-212

Döring, J., Frisch, M., Tittmann, S., Stoll, M., and Kauer, R. (2015). Growth, yield and fruit quality of grapevines under organic and biodynamic management. PLoS ONE 10:e0138445. doi: 10.1371/journal.pone.0138445

dos Santos, T. P., Lopes, C. M., Rodrigues, M. L., de Souza, C. R., Ricardo-daSilva, J. M., Maroco, J. P., et al. (2007). Effects of deficit irrigation strategies on cluster microclimate for improving fruit composition of Moscatel field-grown grapevines. Sci. Hortic. 112, 321-330. doi: 10.1016/j.scientia.2007.01.006

El-Ansary, D. O., Nakayama, S., Hirano, K., and Okamoto, G. (2005). Response of Muscat of Alexandria table grapes to post-veraison regulated deficit irrigation in Japan. Vitis 44, 5-9.

El-Ansary, D. O., and Okamoto, G. (2007). Vine water relations and quality of 'Muscat of Alexandria' table grapes subjected to partial root-zone drying and regulated deficit irrigation. J. Jpn. Soc. Hort. Sci. 76, 13-19. doi: 10.2503/jjshs. 76.13

Girona, J., Marsal, J., Mata, M., Del Campo, J., and Basile, B. (2009). Phenological sensitivity of Berry growth and composition of Tempranillo grapevines (Vitis vinifera L.) to water stress. Aus. J. Grape Wine Res. 15, 268-277. doi: 10.1111/j. 1755-0238.2009.00059.x

Girona, J., Mata, M., del Campo, J., Arbonés, A., Bartra, E., and Marsal, J. (2006). The use of midday leaf water potential for scheduling deficit irrigation in vineyards. Irrig. Sci. 24, 115-127. doi: 10.1007/s00271-005-0015-7

Gouveia, J., Lopes, C. M., Pedroso, V., Martins, S., Rodrigues, P., and Alves, I. (2012). Effect of irrigation on soil water depletion, vegetative growth, yield and berry composition of the grapevine variety Touriga Nacional. Ciência Téc. Vitiv. 27, 115-122.

Greven, M., Green, S., Neal, S., Clothier, B., Neal, M., Dryden, G., et al. (2005). Regulated deficit irrigation (RDI) to save water and improve Sauvignon Blanc quality? Water Sci. Technol. 51, 9-17.

Hamilton, A. J., Stagnitti, F., Xiong, X., Kreidl, S. L., Benke, K. K., and Maher, P. (2007). Wastewater irrigation: the state of play. Vadose Zone J. 6, 823-840. doi: 10.2136/vzj2007.0026

Hickinbotham, A. R., and Williams, R. A. (1933). Soluble salts in non-irrigated vineyards. South Aus. J. Agric. 36, 217-223.

Hochberg, U., Degu, A., Cramer, G. R., Rachmilevitch, S., and Fait, A. (2015). Cultivar specific metabolic changes in grapevines berry skins in relation to deficit irrigation and hydraulic behavior. Plant Physiol. Biochem. 88, 42-52. doi: 10.1016/j.plaphy.2015.01.006

Ilc, T., Werck-Reichart, D., and Navrot, N. (2016). Meta-analysis of the core aroma components of grape and wine aroma. Front. Plant Sci. 7:1472. doi: 10.3389/ fpls.2016.01472

Intrigliolo, D. S., and Castel, J. R. (2006). Vine and soil-based measures of water status in a Tempranillo vineyard. Vitis 45, 157-163.

Intrigliolo, D. S., and Castel, J. R. (2008). Effects of irrigation on the performance of grapevine cv. Tempranillo in Requena, Spain. Am. J. Enol. Vitic. 59, 30-38.

Intrigliolo, D. S., and Castel, J. R. (2009). Response of Vitis vinifera cv. 'Tempranillo' to partial rootzone drying in the field: water relations, growth, yield and fruit and wine quality. Agric. Water Manage. 96, 282-292. doi: 10.1016/j.agwat.2008. 08.001

Intrigliolo, D. S., and Castel, J. R. (2010). Response of grapevine cv. 'Tempranillo' to timing and amount of irrigation: water relations, vine growth, yield and berry and wine composition. Irrig. Sci. 28, 113-125. doi: 10.1007/s00271-009-0164-1

Intrigliolo, D. S., and Castel, J. R. (2011). Interactive effects of deficit irrigation and shoot and cluster thinning on grapevine cv. Tempranillo. Water relations, vine performance and berry and wine composition. Irrig. Sci. 29, 443-454. doi: 10.1007/s00721-010-0252-2

Intrigliolo, D. S., Lizama, V., García-Esparza, M. J., Abrisqueta, I., and Álvarez, I. (2016). Effects of post-veraison irrigation regime on Cabernet Sauvignon grapevines in Valencia, Spain: yield and grape composition. Agric. Water Manage. 170, 110-119. doi: 10.1016/j.agwat.2015.10.020

Intrigliolo, D. S., Pérez, D., Risco, D., Yeves, A., and Castel, J. R. (2012). Yield components and grape composition responses to seasonal water deficits in Tempranillo grapevines. Irrig. Sci. 30, 339-349. doi: 10.1007/s00271-0120354-0

IPCC (2014). “Climate Change 2014: Synthesis Report,” in Contribution of Working Groups I, II and III to the Fifth Assessment Report of the Intergovernmental Panel on Climate Change, eds Core Writing Team, R. K. Pachauri, and L. A. Meyer (Geneva: IPCC), 151.

Jackson, D. I., and Lombard, P. B. (1993). Environmental and management practices affecting grape composition and wine quality-A review. Am. J. Enol. Vitic. 44, 409-430.

Junquera, P., Lissarrague, J. R., Jiménez, L., Linares, R., and Baeza, P. (2012). Longterm effects of different irrigation strategies on yield components, vine vigour, and grape composition in cv. Cabernet-Sauvignon (Vitis vinifera L.). Irrig. Sci. 30, 351-361. doi: 10.1007/s00271-012-0348-y

Kaufmann, A. (1996). Chloride in wine. Dtsch. Lebensmitt. Rundsch. 92, 205-209.

Keller, M. (2010). Managing grapevines to optimize fruit development in a challenging environment: a climate change primer for viticulturists. Aus. J. Grape Wine Res. 16, 56-59. doi: 10.1111/j.1755-0238.2009.00077.x

Keller, M., Romero, P., Gohil, H., Smithyman, R. P., Riley, W. R., Casassa, L. F., et al. (2016). Deficit irrigation alters grapevine growth, physiology, and fruit microclimate. Am. J. Enol. Vitic. 67, 426-435. doi: 10.5344/ajev.2016.16032

Keller, M., Smithyman, R. P., and Mills, L. J. (2008). Interactive effects of deficit irrigation and crop load on Cabernet Sauvignon in an arid climate. Am. J. Enol. Vitic. 59, 221-234.

Kounduras, S., Marinos, V., Gkoulioti, A., Koyseridis, Y., and van Leeuwen, C. (2006). Influence of vineyard location and vine water status on fruit maturation of nonirrigated cv. Agiorgitiko (Vitis vinifera L.). Effects on wine phenolic and aroma components. J. Agric. Food Chem. 54, 5077-5086. doi: 10.1021/jf0605446

Lanari, V., Palliotti, A., Sabbatini, P., Howell, G. S., and Silvestroni, O. (2014). Optimizing deficit irrigation strategies to manage vine performance and fruit composition of field-grown 'Sangiovese' (Vitis vinifera L.) grapevines. Sci. Hortic. 179, 239-247. doi: 10.1016/j.scienta.2014.09.032

Laurenson, S., Bolan, N. S., Smith, E., and McCarthy, M. (2012). Review: use of recycled wastewater for irrigating grapevines. Aus. J. Grape Wine Res. 18, 1-10. doi: 10.1111/j.1755-0238.2011.00170.x

Lavoie-Lamoureux, A., Sacco, D., Rissé, P. A., and Lovisolo, C. (2017). Factors influencing stomatal conductance in response to water availability in grapevine: a meta-analysis. Physiol. Plant. 159, 468-482. doi: 10.1111/ppl.12530

Lund, S. T., and Bohlmann, J. (2006). The molecular basis for wine grape quality-a volatile subject. Science 311, 804-805. doi: 10.1126/science.1118962

Marschner, H. (1986). Mineral Nutrition of Higher Plants. London: Academic Press. Medrano, H., Tomás, M., Martorell, S., Escalona, J. M., Pou, A., Fuentes, S., et al. (2015). Improving water use efficiency of vineyards in semi-arid regions. A review. Agron. Sustain. Dev. 35, 499-517. doi: 10.1007/s13593-0140280-Z

Mendez-Costabel, M. P., Wilkinson, K. L., Bastian, S. E. P., Jordans, C., McCarthy, M., Ford, C. M., et al. (2014). Effect of increased irrigation and additional nitrogen fertilization on the concentration of green aroma compounds in Vitis vinifera L. Merlot fruit and wine. Aust. J. Grape Wine Res. 20, 80-90. doi: 10.1111/ajgw.12062

Merli, M. C., Gatti, M., Galbignani, M., Bernizzoni, F., and Magnanini, E. (2015). Comparison of whole-canopy water use efficiency and vine performance of cv. Sangiovese (Vitis vinifera L.) vines subjected to a post-veraison water deficit. Sci. Hortic. 185, 113-120. doi: 10.1016/j.scienta.2015.01.019

Mira de Orduña, R. (2010). Climate change associated effects on grape and wine quality and production. Food Res. Int. 43, 1844-1855. doi: 10.1016/j.foodres. 2010.05.001

Mirás-Avalos, J. M., Trigo-Córdoba, E., Bouzas-Cid, Y., and Orriols-Fernández, I. (2016). Irrigation effects on the performance of grapevine (Vitis vinifera L.) cv. 'Albariño' under the humid climate of Galicia. OENO One 50, 183-194. doi: 10.20870/oeno-one.2016.50.4.63

Mosse, K. P. M., Lee, J., Leachman, B. T., Parikh, S. J., Cavagnaro, T. R., Patti, A. F., et al. (2013). Irrigation of an established vineyard with winery cleaning agent solution (simulated winery wastewater): vine growth, berry quality, and soil chemistry. Agric. Water Manage. 123, 93-102. doi: 10.1016/j.agwat.2013.02.008 
Mosse, K. P. M., Patti, A. F., Christen, E. W., and Cavagnaro, T. R. (2011). Review: winery wastewater quality and treatment options in Australia. Aus. J. Grape Wine Res. 17, 111-122. doi: 10.1111/j.1755-0238.2011.00132.x

Munitz, S., Netzer, Y., and Schwartz, A. (2017). Sustained and regulated deficit irrigation of field-grown Merlot grapevines. Aus. J. Grape Wine Res. 23, 87-94. doi: 10.1111/ajgw.12241

Myburgh, P. A. (2005). Water status, vegetative growth and yield responses of Vitis vinifera L. cvs. Sauvignon blanc and Chenin blanc to timing of irrigation during berry ripening in the Coastal Region of South Africa. S. Afr. J. Enol. Vitic. 26, 59-67.

Myburgh, P. A. (2006). Juice and wine quality responses of Vitis vinifera L. cvs. Sauvignon blanc and Chenin blanc to timing of irrigation during berry ripening in the Coastal Region of South Africa. S. Afr. J. Enol. Vitic. 27, 1-7.

Myburgh, P. A. (2011a). Response of Vitis vinifera L. cv. Merlot to low frequency drip irrigation and partial root zone drying in the Western Cape Coastal Region-Part I. Soil and plant water status. S. Afr. J. Enol. Vitic. 32, 89-103.

Myburgh, P. A. (2011b). Response of Vitis vinifera L. cv. Merlot to low frequency drip irrigation and partial root zone drying in the Western Cape Coastal Region - Part II. Vegetative growth, yield and quality. S. Afr. J. Enol. Vitic. 32, 104-116.

Naor, A., Bravdo, B., and Hepner, Y. (1993). Effect of post-véraison irrigation level on Sauvignon Blanc yield, juice quality and water relations. S. Afr. J. Enol. Vitic. $14,19-25$.

Netzer, Y., Shenker, M., and Schwartz, A. (2014). Effects of irrigation using treated wastewater on table grape vineyards: dynamics of sodium accumulation in soil and plant. Irrig. Sci. 32, 283-294. doi: 10.1007/s00271-014-0430-8

Ojeda, H., Andary, C., Kraeva, E., Carbonneau, A., and Deloire, A. (2002). Influence of pre- and postveraison water deficit on synthesis and concentration of skin phenolic compounds during berry growth of Vitis vinifera cv. Shiraz. Am. J. Enol. Vitic. 53, 261-267.

Ollé, D., Guiraud, J. L., Souquet, J. M., Terrier, N., Ageorges, A., Cheynier, V., et al. (2011). Effect of pre- and post-veraison water deficit on pranthocyanididn and anthocyanin accumulation during Shiraz berry development. Aus. J. Grape Wine Res. 17, 90-100. doi: 10.1111/j.1755-0238.2010.00121.x

Ou, C., Du, X., Shellie, K., Ross, C., and Qian, M. (2010). Volatile compounds and sensory attributes of wine from cv. Merlot (Vitis vinifera L.) grown under differential levels of water deficit with or without a kaolin-based, foliar reflectant particle film. J. Agric. Food Chem. 58, 12890-12898. doi: 10.1021/jf102587x

Peyrot des Gachons, C., van Leeuwen, C., Tominaga, T., Soyer, J. P., Gaudillère, J. P., et al. (2005). Influence of water and nitrogen deficit on fruit ripening and aroma potential of Vitis vinifera L. cv. Sauvignon blanc in field conditions. J. Sci. Food Agric. 85, 73-85. doi: 10.1002/jsfa.1919

Reynolds, A. G., Lowrey, W. D., Tomek, L., Hakimi, J., and de Savigny, C. (2007). Influence of irrigation on vine performance, fruit composition, and wine quality of Chardonnay in a cool, humid climate. Am. J. Enol. Vitic. 58, 217-228.

Roby, G., and Matthews, M. A. (2004). Relative proportions of seed, skin and flesh, in ripe berries from Cabernet Sauvignon grapevines grown in a vineyard either well irrigated or under water deficit. Aus. J. Grape Wine Res. 10, 74-82. doi: 10.1111/j.1755-0238.2004.tb00009.x

Romero, P., Fernández-Fernández, J. I., and Martínez-Cutillas, A. (2010). Physiological thresholds for efficient regulated deficit-irrigation management in winegrapes grown under semiarid conditions. Am. J. Enol. Vitic. 61, 300-312.

Romero, P., Gil-Muñoz, R., del Amor, F. M., Valdés, E., Fernández, J. I., and Martínez-Cutillas, A. (2013). Regulated deficit irrigation based upon optimum water status improves phenolic composition in Monastrell grapes and wines. Agric. Water Manage. 121, 85-101. doi: 10.1016/j.agwat.2013.01.007

Salón, J. L., Chirivella, C., and Castel, J. R. (2005). Response of cv. Bobal to timing of deficit irrigation in Requena, Spain: water relations, yield, and wine quality. Am. J. Enol. Vitic. 56, 1-8.

Santesteban, L. G., Miranda, C., and Royo, J. B. (2011). Regulated deficit irrigation effects on growth, yield, grape quality and individual anthocyanin composition in Vitis vinifera L. cv. 'Tempranillo'. Agric. Water Manage. 98, 1171-1179. doi: 10.1016/j.agwat.2011.02.011
Santos, J. A., Malheiro, A. C., Pinto, J. G., and Jones, G. V. (2012). Macroclimate and viticultural zoning in Europe: observed trends and atmospheric forecasting. Clim. Res. 51, 89-103. doi: 10.3354/cr01056

Savoi, S., Wong, D. C. J., Arapitsas, P., Miculan, M., Bucchetti Peterlunger, E., Fait, A., et al. (2016). Transcriptome and metabolite profiling reveals that prolonged drought modulates the phenylpropanoid and terpenoid pathway in white grapes (Vitis vinifera L.). BMC Plant Biol. 16:67. doi: 10.1186/s12870-0160760- 1

Schultz, H. R., and Stoll, M. (2010). Some critical issues in environmental physiology of grapevines: future challenges and current limitations. Aus. J. Grape Wine Res. 16, 4-24. doi: 10.1111/j.1755-0238.2009.0074.x

Shellie, K. C. (2010). Water deficit effect on ratio of seed to berry fresh weight and berry weight uniformity in winegrape cv. Merlot. Am. J. Enol. Vitic. 61, 414-418.

Shellie, K. C. (2014). Water productivity, yield, and berry composition in sustained versus regulated deficit irrigation of Merlot grapevines. Am. J. Enol. Vitic. 65, 197-205. doi: 10.5344/ajev.2014.13112

Shellie, K. C., and Bowen, P. (2014). Isohydrodynamic behavior in deficit-irrigated Cabernet Sauvignon and Malbec and its relationship between yield and berry composition. Irrig. Sci. 32, 87-97. doi: 10.1007/s00271-013-0416-y

Stevens, R. M., Harvey, G., and Partington, D. L. (2011). Irrigation of grapevines with saline water at different growth stages: effects on leaf, wood and juice composition. Aus. J. Grape Wine Res. 17, 239-248. doi: 10.1111/j.1755-0.238. 2011.00145.x

Talaverano, I., Valdés, E., Moreno, D., Gamero, E., Mancha, L., and Vilanova, M. (2017). The combined effect of water status and crop level on Tempranillo wine volatiles. J. Sci. Food Agric. 97, 1533-1542. doi: 10.1002/jsfa.7898

Teakle, N. L., and Tyerman, S. D. (2010). Mechanisms of Cl- transport contributing to salt tolerance. Plant Cell Environ. 33, 566-589. doi: 10.1111/j.1365-3040. 2009.02060.x

Trégoat, O., van Leeuwen, C., Choné, X., and Gaudillère, J. P. (2002). Étude du régime hydrique et de la nutrition azotée de la vigne pour des indicateurs physiologiques: influence sur le comportement de la vigne et la maturation du raisin (Vitis vinifera L. cv. Merlot, 2000, Bordeaux). J. Int. Sci. Vigne Vin 36, $133-142$.

Trigo-Córdoba, E., Bouzas-Cid, Y., Orriols-Fernández, I., and Mirás-Avalos, J. M. (2015). Effects of deficit irrigation on the performance of grapevine (Vitis vinifera L.) cv. 'Godello' and 'Treixadura' in Ribeiro, NW Spain. Agric. Water Manage. 161, 20-30. doi: 10.1016/j.agwat.2015.07.011

van Leeuwen, C., Trégoat, O., Choné, X., Bois, B., Pernet, D., and Gaudillère, J.-P. (2009). Vine water status is a key factor in grape ripening and vintage quality for red Bordeaux wine. How can it be assessed for vineyard management purposes? J. Int. Sci. Vigne Vin 43, 121-134. doi: 10.20870/oeno-one.2009.43.3.798

Walker, R. R., Blackmore, D. H., Clingeleffer, P. R., and Emanuelli, D. (2014). Rootstock type determines tolerance of Chardonnay and Shiraz to long-term saline irrigation. Aus. J. Grape Wine Res. 20, 496-506. doi: 10.1111/ajgw.12094

Walker, R. R., Read, P. E., and Blackmore, D. H. (2000). Rootstock and salinity effects on rates of berry maturation, ion accumulation and colour development in Shiraz grapes. Aus. J. Grape Wine Res. 6, 227-239. doi: 10.1111/j.1755-0238. 2000.tb00183.x

Williams, L. E. (2012). Interaction of applied water amounts and leaf removal in the fruiting zone on grapevine water relations and productivity of Merlot. Irrig. Sci. 30, 363-375. doi: 10.1007/s00271-012-0355-z

Conflict of Interest Statement: The authors declare that the research was conducted in the absence of any commercial or financial relationships that could be construed as a potential conflict of interest.

Copyright (c) 2017 Mirás-Avalos and Intrigliolo. This is an open-access article distributed under the terms of the Creative Commons Attribution License (CC BY). The use, distribution or reproduction in other forums is permitted, provided the original author(s) or licensor are credited and that the original publication in this journal is cited, in accordance with accepted academic practice. No use, distribution or reproduction is permitted which does not comply with these terms. 